See Article page 335

\section{Commentary: Mitigating the other pandemic}

\author{
Jahnavi Kakuturu, MD, Charlotte Spear, MD, and \\ J. W. Awori Hayanga, MD, MPH, FACS, FRCS, FCCP
}

In this article, Javidfar and colleagues ${ }^{1}$ address the use of extracorporeal support in the patient with obesity. The article is timely and relevant in view of the everincreasing proportion of patients with obesity requiring support for acute severe respiratory failure. Perhaps, more poignant, nevertheless, is the coincident backdrop of the coronavirus disease 2019 (COVID-19) pandemic. The disproportionate risk of obesity is manifest in the median body mass index of 33 in patients requiring extracorporeal membrane oxygenation (ECMO). ${ }^{2} \mathrm{~A}$ better understanding of the confluence of these 2 epidemics is therefore likely to be of value to the readership and the surgical community at large as they each grapple with an ever-increasing volume of patients with obesity requiring extracorporeal support.

Recent metanalysis has demonstrated that obesity may exacerbate COVID-19 by an increased expression of angiotensin-converting enzyme, to which the virus spike protein binds and renders the lungs susceptible to attack. ${ }^{3}$ Obesity is also associated with an exacerbation of inflammatory and immune responses that may induce an exaggerated inflammatory response. ${ }^{4}$ The independent risk, therefore, posed by obesity is certainly worthy of evaluation in view of the inherent challenges in cannulation, ventilatory management, and rehabilitation that characterize the care of this cohort of patients. Javidfar and colleagues ${ }^{1}$ provide pragmatic insight into the use of transpulmonary esophageal pressure measurement to guide titration of positive end expiratory pressure as well as in the use of unconventional cannulation strategies to optimize venous drainage. The authors deftly navigate the controversy regarding obesity

\footnotetext{
From the Department of Cardiovascular and Thoracic Surgery, WVU Heart and Vascular Institute, West Virginia University, Morgantown, WVa.

Disclosures: The authors reported no conflicts of interest.

The Journal policy requires editors and reviewers to disclose conflicts of interest and to decline handling or reviewing manuscripts for which they may have a conflict of interest. The editors and reviewers of this article have no conflicts of interest.

Received for publication Aug 19, 2021; revisions received Aug 19, 2021; accepted for publication Aug 20, 2021; available ahead of print Aug 25, 2021.

Address for reprints: J. W. Awori Hayanga, MD, MPH, FACS, FRCS, FCCP, Department of Cardiovascular and Thoracic Surgery, West Virginia University, 1 Medical Center Dr, Morgantown, WV 26506 (E-mail: jeremiah.hayanga@wvumedicine.org). JTCVS Techniques 2021;10:349

2666-2507

Copyright (C) 2021 The Author(s). Published by Elsevier Inc. on behalf of The American Association for Thoracic Surgery. This is an open access article under the CC BY license (http://creativecommons.org/licenses/by/4.0/).

https://doi.org/10.1016/j.xjtc.2021.08.033
}

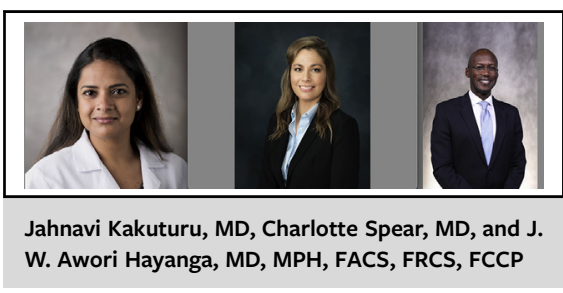

CENTRAL MESSAGE

Navigating the challenge of obesity in extracorporeal support requires careful attention.

as an independent risk factor for death on extracorporeal support. Indeed, this has been a source of contention in the ECMO literature for several years, and there is vociferous opinion both for and against the assertion that it is. ${ }^{4,5}$

It is plausible, nevertheless, that the greater potential for cannulation injury may be responsible for most of the excess mortality. In stark contradistinction, however, once on extracorporeal support, obesity may, nevertheless, proffer a survival advantage. Indeed, using the Predicting Death for Severe ARDS (PRESERVE) scoring to identify factors associated with death, for instance, one observes that obesity represents a 2-point reduction in risk. Ostensibly, therefore, this would favor a lower mortality in patients with obesity. The authors steer clear of any recommendation as to type or preferred technique of tracheostomy, which would have likely added pragmatic value to the narrative beyond their somewhat tempered recommendation for early tracheostomy. Obesity, nonetheless, continues to be a somewhat-enigmatic feature of extracorporeal support and bears with it a unique set of challenges equally as worthy of discussion as they are of mitigation.

\section{References}

1. Javidfar J, Zaaqoq AM, Yamashita MH, Eschun G, Jacobs JP, Heinsar S, et al. Venovenous extracorporeal membrane oxygenation in obese patients. J Thorac Cardiovasc Surg Tech. 2021;10:335-48.

2. Barbaro RP, MacLaren G, Boonstra PS, Iwashyna TJ, Slutsky AS, Fan E, et al; Extracorporeal Life Support Organization. Extracorporeal membrane oxygenation support in COVID-19: an international cohort study of the Extracorporeal Life Support Organization registry. Lancet. 2020;396:1071-8.

3. Csige I, Ujvárosy D, Szabó Z, Lőrincz I, Paragh G, Harangi M, et al. The impact of obesity on the cardiovascular system. J Diabetes Res. 2018;2018:3407306.

4. Yang J, Tian C, Chen Y, Zhu C, Chi H, Li J. Obesity aggravates COVID-19: an updated systematic review and meta-analysis. J Med Virol. 2021;93:2662-74.

5. Simonnet A, Chetboun M, Poissy J, Raverdy V, Noulette J, Duhamel A, et al; LICORN and the Lille COVID-19 and Obesity study group. High prevalence of obesity in severe acute respiratory syndrome coronavirus-2 (SARS-CoV-2) requiring invasive mechanical ventilation. Obesity (Silver Spring). 2020;28:1195-9.

6. Schmidt M, Zogheib E, Rozé H, Repesse X, Lebreton G, Luyt CE, et al. The PRESERVE mortality risk score and analysis of long-term outcomes after extracorporeal membrane oxygenation for severe acute respiratory distress syndrome. Intensive Care Med. 2013;39:1704-13. 